ATTHULAB:

Islamic Religion Teaching E Learning Journal

Volume 5 Nomor 1 Tahun 2020

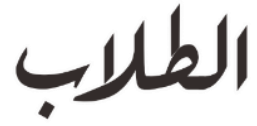

http://journal.uinsgd.ac.id./index.php/atthulab/

\title{
Perbandingan Akhlak Siswa Berasrama dengan Non Asrama SMA Boarding School
}

\author{
Ratu Suntiah'), Miftahul Fikri2), dan Muhammad Hasby Assidiqi3) \\ Jurusan Pendidikan Agama Islam \\ Universitas Islam Negeri Sunan Gunung Djati Bandung \\ Jl. Soekarno Hatta Cimincarang Kec. Gedebage Kota Bandung, Jawa Barat, Indonesia \\ 1)Email: ratu.suntiah@uinsgd.ac.id \\ 2)Email: miftahulfikrisiwa@uinsgd.ac.id \\ 3)hasbyalihasani@gmail.com
}

\begin{abstract}
The study aims to find out the moral difference between boarding students and non-dorm students. This research is a quantitative study with a comparative design of two free variables with survey research design. Poll instruments are disseminated with the provisions of accidental sampling techniques. The results showed that the quality of the boarding school students received a total score of 95.14 with an average of 3.8 and a percentage worth $76 \%$. Meanwhile, the quality of non-dorm students get a total score of 91 with an average of 3.64, a percentage worth $73 \%$. Comparative quality of dormitory students with non-dormitories only 3\%. Then the hypotheses submitted correspond to the results of the study, although not reaching a significant level. This shows the role that dormitories have very few positive impacts and increasing student morality is no easy thing. Because of moral enhancement even in the slightest level it is invaluable to be safeguarded and to add hope to improve the student's moral potential better and still many aspects that can be improved through the boarding system.

Keywords:

Moral; Hostel; Non-Dormitory
\end{abstract}

\begin{abstract}
Abstrak: Penelitian ini bertujuan untuk mengetahui perbedaan akhlak antara siswa berasrama dengan siswa non asrama. Penelitian ini merupakan peneltian kuantitatif dengan jenis rancangan komparatif dua variabel bebas dengan desain penelitian survei. Instrumen angket yang disebarkan dengan ketentuan teknik sampling aksidental. Hasil penelitian menunjukan bahwa kualitas akhlak siswa berasrama mendapatkan skor total 95,14 dengan rata-rata 3,8 dan persentase senilai 76\%. Sementara itu, kualitas akhlak siswa nonasrama mendapatkan skor total 91 dengan rata-rata 3,64, persentase senilai $73 \%$. Kualitas perbandingan akhlak siswa asrama dengan non-asrama hanya 3\%. Maka hipotesis yang diajukan sesuai dengan hasil penelitian, walaupun tidak mencapai taraf yang signifikan. Hal ini menunjukan peran asrama memiliki dampak positif yang sangat sedikit dan meningkatkan akhlak siswa bukanlah perkara mudah. Sebab peningkatan akhlak walaupun dalam taraf yang sedikit itu sangat berharga untuk dijaga serta menambah harapan untuk meningkatkan potensi akhlak siswa lebih baik lagi, serta masih banyak aspek yang bisa ditingkatkan melalui sistem asrama.
\end{abstract}

Kata Kunci:

Akhlak; Asrama; Non-Asrama

DOI: http:/ /dx.doi.org/10.15575/ath.v5i1.5216

Received: 07, 2019. Accepted: 04, 2020. Published: 04, 2020.

\section{PENDAHULUAN}

Problematika anak di Indonesia yang di-informasikan Ikhsanuddin (2018) melalui berita online detik.com bahwa "Komisi Perlindungan Anak Indonesia (KPAI). telah mencatat ada 1.885 kasus pada semester pertama 2018. Dari angka itu, anak berhadapan dengan hukum $(\mathrm{ABH})$ seperti jadi pelaku narkoba, mencuri, hingga asusila menjadi kasus yang paling banyak. Kebanyakan anak masuk Lembaga Pemasyarakatan Khusus Anak 
(LPKA) karena mencuri sebanyak 23,9 persen. Selanjutnya, kasus narkoba 17,8 persen, kasus asusila 13,2 persen dan lainnya. Dalam kasus ini, KPAI menyoroti pola asuh ABH. KPAI menilai ada kesalahan pengawasan orang tua terhadap anaknya". Permasalahan dalam pergaulan anak harus diperhatikan dan diselesaikan, karena jika dibiarkan degradasi akhlak pada anak semakin meningkat. Kondisi saat ini semakin memprihatinkan Firmansyah (2018) memberitakan dalam media online metro.tempo.co bahwa "KPAI mencatat kasus tawuran di Indonesia meningkat 1,1 persen sepanjang $2018^{\prime \prime}$.

Pengawasan orang tua terhadap anak, menurut berita di atas merupakan sebuah fenomena dan akar masalah yang sangat memprihatinkan, sebab adanya oknum orang tua yang tidak memperhatikan pergaulan sosial anak ketika mereka berada di lingkungan umum. Namun tidak semua orang tua salah dalam membimbing anak ketika di rumah dan lingkungan, banyak juga orang tua yang berhasil membimbing anak di rumah.

Aktivitas siswa di rumah dan di asrama tentu akan berbeda, sehingga kendala yang mereka hadapi di lingkungan tentu tidak sama. Rumah adalah tempat tinggal yang langsung berdampingan dengan masyarakat, kegiatan di rumah cenderung fleksibel dan tata tertib yang diterapkan bersifat kondisional serta pengawasan dan bimbingan adalah tugas keluarga. Sedangkan asrama adalah tempat tinggal yang di isi oleh anggota asrama dan para pembina, kegiatan di asrama terjadwal, peraturan dan sanksi adalah tata tertib yang harus diterapkan, serta pengawasan dan bimbingan di-amanatkan kepada para pembina asrama.

Segala sesuatu pasti ada kendala yang dihadapi begitu juga di asrama, permasalahan yang ada di asrama menurut Bapak Muhammad Burhanul Asfia ketika di wawancarai pada hari Jum'at, tanggal 10 November 2018 beliau mengutarakan: "Antusias ngaji kurang, ada yang beberapa yang berkata kasar, terkadang sopan santun kepada pembina asrama kurang, merusak fasilitas secara sengaja" namun hal tersebut tidak dibiarkan begitu saja, ada sanksi berupa "Hukuman, teguran dan persidangan kalau lebih dari tiga kali melanggar".

Kunjungan survei ke SMA Pribadi Bilingual Boarding School pada jam 11.00 WIB hari senin tanggal 26 November 2018 menghasilkan data wawancara dari seorang Pembina Asrama yang bernama Bapak Niko Noviansyah, S.Pd.I, beliau menyatakan bahwa : "Tujuan adanya asrama adalah untuk mempermudah kegiatan belajar agar lebih fokus, menjaga pergaulan siswa dan melihat perkembangan siswa, tujuan sekolah dalam membina akhlak dan intelektualitas bisa lebih tercapai."

Upaya pembentukan akhlak dimaksimalkan dengan adanya pembinaan dan pengawasan, selama siswa di asrama siswa diwajibkan untuk mentaati tata tertib dan kegiatan, serta tidak keluar asrama sebelum meminta izin tertulis kepada pembina asrama untuk keperluan tertentu.

Fasilitas dan sekaligus program asrama diasumsikan; siswa yang berasrama akan lebih baik akhlaknya daripada siswa non asrama, walaupun demikian tidak menutup kemungkinan siswa diluar asrama mampu memiliki akhlak yang lebih baik, berkat bimbingan orang tua, pengajian private, dan kemungkinan menjadi remaja Masjid di lingkungannya.

Manfaat Teoretik, hasil penelitian ini diharapkan bermanfaat bagi pengembangan ilmu pengetahuan, menambah khazanah tentang taraf dan perbandingan akhlak siswa di asrama dan non asrama. Adapun manfaat secara praktis, penelitian ini diharapkan menjadi bahan masukan dan menambah semangat serta inspirasi bagi bagi para pemilik yayasan yang memiliki asrama dalam membentuk akhlak generasi penerus bangsa. 
Pengujian ada atau tidaknya perbedaan variabel $X$ (Akhlak siswa berasrama) dengan variabel $\mathrm{Y}$ (Akhlak siswa non asrama), maka penulis mengajukan hipotesa sebagai berikut:

Hipotesis Nihil :

(Ho)

Hipotesis Alternatif :

(Ha)
Tidak terdapat perbedaan yang signifikan Akhlak siswa bersarama dengan non asrama di sekolah SMA Pribadi Bilingual Boarding School Bandung.

Terdapat perbedaan yang signifikan Akhlak siswa bersarama dengan non asrama di sekolah SMA Pribadi Bilingual Boarding School Bandung.

Berdasarkan hipotesis di atas, penulis memiliki dugaan sementara bahwa terdapat Akhlak siswa berasrama lebih baik dibandingkan dengan siswa non asrama di sekolah SMA Pribadi Bilingual Boarding School Bandung. Penulis sepakat dengan pernyataan Ha di atas. Adapun untuk kebenarannya, perlu dilakukan penelitian di sekolah yang bersangkutan

Skripsi Caswa (208011000048) Fakultas Ilmu Tarbiyah dan Keguruan Universitas Islam Negeri Syarif Hidayatullah Jakarta, lulus tahun 2013 berjudul "Perbandingan Prestasi Belajar Pendidikan Agama Islam Siswa Berasrama dengan Non Asrama di SMP Kharisma Bangsa Tangerang Selatan". Adapun yang menjadi variabel X adalah Prestasi Siswa Berasrama dan yang menjadi variabel Y adalah Prestasi Siswa Non asrama. Hasil penelitian menunjukan bahwa dari hasil angket, respon siswa terhadap masalah keberagamaan cukup, pembinaan siswa asrama berdasarkan observasi penulis juga sudah baik dilihat dari kegiatan-kegiatan keagamaan yang dilakukan di asrama. Adapun dilihat dari uji beda berdasarkan hasil UK PAI dan nilai Pendidikan Agama Islam berdasarkan nilai raport, mendapatkan hasil bahwa t hitung dari UK PAI sebesar 0,004 dan thitung berdasarkan nilai raport adalah 0,63 dan dibandingkan dengan $\mathrm{db} a$ $=0,05 t(0,05 ; 28)$ adalah 1,70 maka 0,004 dan $0,63<1,70$. Dengan demikian tidak ada perbedaan yang signifikan antara prestasi belajar siswa yang tinggal di asrama dan siswa yang non asrama pada mata pelajaran Pendidikan Agama Islam di sekolah Kharisma Bangsa Tangerang Selatan dari segi kognitif. Tinggal di asrama tidak memberi pengaruh kemampuan kognitif siswa dalam penguasaan materi Pendidikan Agama Islam. Kemungkinan besar pengaruh asrama terhadap siswa yang tinggal diasrama dalam bentuk sikap mental, prilaku keagamaan, sikap sosial dan kemandirian, yang terbentuk melalui interaksi dan kebiasaan di asrama.

Skripsi yang berkaitan dengan asrama yang sudah diteliti adalah inspirasi penyusun untuk melaksanakan penelitian dalam rangka menjawab tantangan zaman dan perkembangan ilmu pengetahuan, terutama ingin melanjutkan jawaban dan pertanyaan penelitian terdahulu terutama pada aspek akhlak dalam hal prilaku agama, sikap mental dan sikap sosial serta cinta terhadap lingkungan. Terlebih pada saat ini untuk membentuk akhlak siswa dan menerapkan sistem asrama dengan maksimal, akan lebih banyak tantangan dibandingkan masa yang telah lalu. Adapun pokok pembahasan penelitian ini lebih menekankan pada akhlak siswa berasrama dengan nonasrama.

Manusia dan akhlak tidak bisa dipisahkan, karena akhlak selalu melekat dalam diri yang diimplementasikan melalui perbuatan. Melekatnya jiwa dan akhlak ialah ekspresi atau tindakan yang spontanitas dari dalam jiwa, sehingga melupakan pemikiran dan pertimbangan. 
Manusia akan menjadi mulia jika mengerjakan perkara mulia, sebaliknya manusia akan menjadi buruk jika melakukan perbuatan terhina. Mulia dan terhina adalah sebuah pilihan dalam kehidupan, beruntunglah bagi yang melakukan kebaikan, merugilah bagi yang melakukan perbuatan tercela.

Akhlak sebagai prinsip yang harus dimiliki siswa akan terwujud jika lingkungan yang siswa tempati terdapat pemimpin baik orang tua, guru ataupun pembina untuk dijadikan sebagai panutan dan teladan yang pantas di dengar nasehat mereka dan mentaati perkara baik yang mereka perintahkan. Sehingga siswa sebagai generasi muda penerus bangsa, terutama jenjang pendidikan SMA harus benar-benar diperhatikan dan diawasi pergaulan mereka, agar akhlak siswa tidak mengalami degradasi, bahkan diharapkan akhlak generasi penerus bangsa semakin meningkat agar masa depan bangsa lebih indah, damai, adil dan makmur sentosa.

Bagi siswa dan semua orang, memiliki akhlak yang baik adalah sebuah kewajiban yang harus selalu melekat dalam diri, sebab dengan memiliki akhlak yang baik menjalani kehidupan akan lebih indah dan ter-arah. Jika akhlak baik tertanam sejak kecil maka akan terbiasa untuk melakukan kebaikan kapanpun dan dimanapun, namun jika belum terbiasa maka akan lebih sulit untuk mengamalkan akhlak yang baik karena harus terlebih dahulu menghilangkan kebiasaan buruk dan bertekad untuk menjadi pribadi yang lebih baik. Siswa harus terjaga dan terjamin keberhasilannya. bahkan permainan catur dapat dijadikan sebuah pelajaran, jika bidak atau pion ingin menjadi menteri maka majulah terus dan jaga dia jangan sampai mati ataupun terhalangi.

Akhlak memiliki karakteristik yang universal. Artinya ruang lingkup dalam pandangan Islam sama luasnya dengan ruang lingkup pola hidup dan tindakan manusia. Ruang lingkup akhlak ada tiga. Yaitu akhlak terhadap Allah, akhlak terhadap sesama manusia, dan akhlak terhadap alam (Syahriansyah, 2014:201).

Perbuatan moral merupakan tindakan manusia sebagai manusia. Manusia adalah ciptaan Tuhan yang memiliki akal budi. Perbuatan moral mencetuskan kodrat manusiawi dan sekaligus mulia (Dewantara, 2017:17). Manusia mengalami proses pendangkalan dalam menghayati kehidupannya, kehidupan sesamanya, dan kehidupan bersamanya dengan orang lain. krisis nilai dengan demikian tidak sama sekedar sebagai suatu krisis konsep atau gagasan atau ide mengenai kebaikan. krisis nilai adalah krisis kehidupan dalam artian etis dan moral secara mendalam dan real (Dewantara, 2017:45).

Rumah adalah tempat tinggal yang langsung berdampingan dengan masyarakat, kegiatan di rumah cenderung fleksibel dan tata tertib yang di terapkan bersifat kondisional serta pengawasan dan bimbingan adalah tugas keluarga. Kecendrungan sifat fleksibel dan kondisional yang diterapkan dirumah memiliki penerapan yang berbeda-beda dalam setiap keluarga dan peraturan dirumah lebih banyak tersirat dibandingkan dengan tersurat. Waktu dan peraturan yang sifat nya luwes tentu memiliki dampak positif serta berdampak negatif jika terlalu bebas dan lupa batas, yakni sebagai contoh dirumah bisa mengutamakan pekerjaan yang lebih di inginkan dan bisa menunda waktu untuk beritirahat sejenak.

Sosok keluarga di rumah adalah sebuah kenyamanan yang tidak tergantikan. Perlindungan dan perhatian sangat terasa jika berada di rumah, peningkatan semangat dan pertumbuhan anak dirumah sangatlah signifikan. keamanan dan persediaan makanan juga kesenangan mudah untuk didapatkan. Namun sikap manja yang berlebihan bisa membuat seorang anak malas untuk berjuang.

Keluarga-keluarga sekarang ini terlihat lebih menerapkan suasana yang terbuka, bicara terbuka antara seluruh anggota keluarga. Sedikit berbeda dengan masa yang lalu, 
saat orang tua dan anak terkadang punya hambatan untuk berkomunikasi dengan lancar dan terbuka. Mungkin tidak semua keluarga begitu, tapi sepertinya sebagian besar keluarga menerapkan pola yang kurang lebih demikian. Tidak semua hal dapat dibicarakan dengan orang tua. Anak perlu memilah-milah dulu, apa saja yang bisa disampaikan atau ditanyakan kepada orang tua. Ada kalanya orang tua terlihat agak 'kesal' karena tidak dapat menjawab pertanyaan-pertanyaan anaknya. Orang tua sebagai tokoh otoritas dalam keluarga seringkali menempatkan diri sebagai tokoh panutan yang selalu tahu dan tidak terbantahkan. (Muftie, 2017: 97).

Lingkungan masyarakat adalah wilayah yang luas, dan tak sebatas lokasi yang berdampingan dengan rumah saja, namun terdapat mahluk sosial yang bertebaran sampai penjuru dunia dan memiliki beraneka budaya. Maka daya jelajah anak terhadap lingkungan sosial sebisa mungkin harus diawasi oleh orang tua, yakni dengan cara memperhatikan pergaulan anak serta orang tua harus tahu dan kenal dengan siapa anaknya berteman, sehingga mudah untuk menanyakan kegiatan anak di lingkungan sosial.

Non asrama adalah lingkungan yang terlepas dari fasilitas, kegiatan dan peraturan asrama serta tidak ada organisasi tertentu seperti pembina dan pemimpin serta anggota yang terstrukstur. Oleh karena itu siswa Non asrama adalah peserta didik selain anggota asrama, yakni mereka yang tinggal di rumah bersama keluarga dan sebagainya.

Siswa di lingkungan Non asrama dituntut agar mampu melaksanakan kegiatan yang berada di lingkungan keluarga dan sosial mereka, baik kegiatan yang tersurat maupun tersirat. akan tetapi lingkungan harus tetap ter-kontrol dengan pembinaan atau pola asuh orang tua atau keluarga maupun tetangga melalui pendekatan emosional dan sebagainya.

Bronfenbrenner mengemukakan ada 5 (lima) sistem lingkungan yang dapat memengaruhi perkembangan anak, yaitu: mikrosistem, mesosistem, ekosistem, makrosistem, dan kronosistem. Dari lima sistem lingkungan tersebut yang erat kaitannya dengan proses tumbuh kembang anak adalah mikrosistem, yakni lingkungan tempat anak menghabiskan banyak waktu dalam kehidupannya (Sunarti, 2015:27).

Asrama adalah salah satu upaya sadar dan ter-organisir untuk meningkatkan akhlak siswa lebih baik lagi, walaupun tidak menutup kemungkinan ada beberapa siswa yang memiliki akhlak lebih baik, meskipun mereka tidak ber-asrama. Kegiatan dan peraturan di asrama yang akan mempengaruhi dan merubah akhlak siswa dalam keseharian mereka, sehingga menjadikan mereka untuk terbiasa berbuat baik dan mentaati disiplin.

Siswa adalah aset berharga yang harus dijaga dan dilindungi serta ditingkatkan pertumbuhannya dan perkembangannya, terutama diajarkan sedini mungkin aspek utama dalam kehidupan, seperti: akhlak terhadap Allah, akhlak terhadap diri sendiri, akhlak terhadap sesama manusia dan akhlak terhadap lingkungan. Tujuan siswa memiliki empat aspek tersebut agar siswa mampu memantaskan diri sebagai manusia sempurna.

Perbandingan digunakan sebagai sarana berlomba-lomba dalam kebaikan, dengan demikian semangat untuk mengukir prestasi serta menjadi insan yang sholeh dan sholehah mengalami peningkatan yang cepat. Oleh karena itu siswa yang memiliki akhlak yang tinggi terhadap terutama diri sendiri tidak akan tahu langkah apa saja yang harus dilakukan untuk mengembangkan diri menjadi lebih baik, sehingga semangat selalu terjaga dan terhindar dari sikap suka mengeluh dan putus asa.

Lingkungan rumah orang tua dan lingkungan asrama merupakan tempat tinggal yang baik dalam meningkatkan hasil belajar siswa. Lingkungan rumah orang tua dan 
lingkungan asrama tentunya menginginkan keberhasilan yang baik bagi siswa yang tinggal di dalamnya (Afwan, 2017: 11).

Antara siswa yang tinggal di asrama dengan yang tinggal di rumah mempunyai perbedaan. Perbedaan itu terletak pada keseharian siswa. Dimana siswa yang tinggal di asrama dalam kesehariannya selalu dibatasi oleh peraturan-peraturan yang berlaku, sedangkan siswa yang tinggal di rumah cenderung bebas dalam menentukan aktivitasnya. Mereka yang tinggal di rumah biasa membaur dengan semua orang, baik itu dengan yang masih sekolah, atau yang sudah selesai sekolah dan bahkan yang tidak sekolah sekalipun. Dengan keadaan seperti ini maka siswa yang tinggal di rumah harus pintar dalam memilih teman bergaul dan harus pandai-pandai dalam menggunakan waktunya baik itu untuk belajar ataupun bermain (Lestari, 2019: 125).

Jika siswa berada dilingkungan yang akif belajar dan berdisiplin tinggi memaksa siswa juga untuk disiplin dan giat belajar karena melihat secara langsung persaingan yang terjadi antara satu siswa dengan siswa yang lain. Sedangkan siswa yang tinggal dilingkungan yang di huni oleh varian aktivitasnya menyebabkan siswa memilih lingkungan yang akan siswa ambil sebagai kebiasaannya sehari-hari (Lestari, 2019: 134).

Sekolah yang baik adalah sekolah yang peduli terhadap perkembangan akhlak siswa, sebab nama baik sekolah akan terangkat jika siswa/i yang mereka didik memiliki akhlak yang baik, sehingga tidak melakukan perbuatan buruk dan memalukan. Sebaliknya, jika sekolah ataupun lembaga pendidikan tidak mengajarkan dan menanamkan akhlak dalam diri siswa/i yang mereka miliki maka dalam waktu dekat akan banyak siswa/ i yang memalukan dan merusak diri mereka dan nama baik sekolah.

Dengan adanya sistem asrama maka memberikan dampak positif bagi kehidupan siswa yaitu mengajarkan siswa untuk lebih mandiri karena mereka hidup tanpa ada dan mandiri terhadap dirinya, diajarkan siswa untuk saling mengerti karena siswa berasrama kebanyakan datang dari luar daerah. sehingga membuat siswa untuk bertoleransi, siswa dapat mengembangkan potensi yang ada pada diri, siswa dapat hidup lebih teratur karena siswa berasrama memiliki aturan dan penjadwalan sesuai waktu (Usrah, 2018: 102).

Sekolah berasrama juga terdapat peraturan tertulis yang mengatur para siswa mulai dari bangun tidur sampai tidur kembali. semua itu merupakan peraturan yang harus ditepati dan bila dilanggar akan mndapatkan sanksi dari pengurus. Selain itu siswa brasrama juga memiliki kesempatan bertanya kepada teman seangkatan maupun kepada kakak angkatan jika ada suatu pelajaran yangtidak dimengerti, sedangkan siswa non asrama belum tentu memiliki kesempatan seperti itu. Oleh karena itu, siswa berasrama harus dapat memanfaatkan waktu yang telah disediakan dengan sebaikbaiknya. (Usrah, 2018: 103).

Asrama sebagai sarana penunjang akhlak adalah solusi untuk mencegah degradasi akhlak dimanapun manusia berada, yakni dengan syarat menerapkan unsurunsur islami sebagai rahmatan lil alamin. Maka proses pendidikan dan dakwah berjalan dalam satu nafas untuk meraih tujuan hidup yang mulia.

\section{METODE PENELITIAN}

Penelitian ini merupakan peneltian kuantitatif dengan jenis rancangan komparatif dua variabel bebas dengan desain penelitian survei. Desain dalam penelitian ini yaitu menggunakan rancangan perbandingan kelompok serta menggunakan sumber data primer yaitu data yang didapat penulis secara langsung tanpa pihak ketiga, baik itu secara lisan maupun tulisan. Data tersebut diperoleh dari hasil wawancara terhadap 
pembina asrama, dan angket terhadap siswa di SMA Pribadi Bilingual Boarding School Bandung.

Jumlah populasi siswa di SMA Pribadi Bilingual Boarding School adalah 190 orang. Siswa yang berasrama berjumlah 115 orang dan non-asrama 75 orang. Pengambilan sampel menggunakan metode teknik aksidental. Metode Sampling aksidental adalah teknik penentuan sampel berdasarkan kebetulan, yaitu siapa saja yang secara kebetulan bertemu dengan peneliti dapat digunakan sebagai sampel, bila dipandang orang yang kebetulan ditemui itu sesuai sebagai sumber data (Rozaini Nasution, 2003).

Dalam teknik sampling aksidental, pengambilan sampel tidak ditetapkan lebih dahulu. Peneliti langsung saja mengumpulkan data dari unit sampling yang ditemui (Rozaini Nasution, 2003), sebab prosedur pembagian kuisioner menggunakan google formulir yang disebarkan via Whats App ke grup kelas dan diisi secara kebetulan serta dijadikan sebagai sumber data. Maka data yang telah diterima oleh peneliti terkait kuisioner yang telah dijawab siswa, ada 28 siswa asrama dan 18 siswa non-asrama dengan total sampel/ koresponden 46 siswa.

Skala yang digunakan dalam angket ini adalah skala likert. Skala likert adalah segala yang digunankan untuk mengukur sikap, pendapat, dan persepsi seseorang atau kelompok orang tentang fenomena sosial (Sugiyono, 2013:93).

Sementara itu, analisis data kuantitatif menggunakan langkah-langkah sebagai berikut (Nurjaman, 2018:58-59):

a. Seleksi data, yakni proses dimana data yang telah dikumpulkan akan diteliti dan diseleksi kembali. Tujuannya yakni untuk mendapatkan data yang sesuai dan mengetahui kualitas data tersebut yang dapat digunakan untuk keperluan berikutnya.

b. Klasifikasi data, yakni memilah dan mengklasifikasikan jawaban dari para responden menurut kategorinya masing-masing. Tujuannya yakni supaya data relevan dengan permasalahan yang tengah diajukan. Proses pengklasifikasian ini juga sering disebut dengan koding.

c. Tabulasi data, yakni suatu proses untuk mengetahui frekuensi dari setiap alternatif jawaban. Frekuensi dari masing-masing kategori dihitung. Lalu kemudian data tersebut disusun dalam bentuk tabel.

d. Menafsirkan data, yakni menganalisa dan juga menafsirkan data yang sudah terkumpul dengan kerangka pemikiran masalah yang diajukan.

e. Menarik kesimpulan dari pengolahan data, yakni dengan menghitung analisis tabulasi sehingga akan didapatkan persentasi.

\section{HASIL PENELITIAN DAN PEMBAHASAN}

Penelitian ini dilakukan untuk mengetahui perbedaan antara akhlak siswa asrama dan non-asrama di SMA Pribadi Bandung, dalam hal ini peneliti melakukan penilaian pada aspek-aspek akhlak yang berisikan item negatif dan item positif pada tabel 1 berikut:

\section{Tabel 1}

Aspek Pembahasan Akhlak 


\begin{tabular}{|c|c|}
\hline $\begin{array}{l}\text { No } \\
\text { Item }\end{array}$ & Aspek Pembahasan Akhlak \\
\hline 1. & Berdo'a setelah dan sesudah melakukan aktifitas \\
\hline 2. & Melaksanakan sholat lima waktu/ beribadah \\
\hline 3. & $\begin{array}{l}\text { Mengingatkan dan mengajak teman untuk melaksanakan } \\
\text { kebaikan }\end{array}$ \\
\hline 4. & Mengeluh ketika do'a dan keinginan tidak tercapai \\
\hline 5. & Malas beribadah dan berdo'a ketika sedang bahagia \\
\hline 6. & Saya sering membaca al-Qur'an/ kitab suci \\
\hline 7. & Ingin selalu dipuji orang lain \\
\hline 8. & Berbohong ketika berbicara \\
\hline 9. & Suka memarahi orang lain \\
\hline 10. & Sulit untuk memaafkan kesalahan orang lain \\
\hline 11. & $\begin{array}{l}\text { Selalu berbakti terhadap orang tua dan guru serta tidak } \\
\text { membuat mereka marah }\end{array}$ \\
\hline 12. & $\begin{array}{l}\text { Suka mengganggu ketertiban dan kenyamanan serta merusak } \\
\text { fasilitas umum }\end{array}$ \\
\hline 13. & Sering sholat berjamaah \\
\hline 14. & guh-sungguh da \\
\hline 15. & $\begin{array}{l}\text { Saya suka berlomba-lomba dalam kebaikan dan ingin menjadi } \\
\text { siswa yang berprestasi }\end{array}$ \\
\hline 16. & $\begin{array}{l}\text { Bertanggung jawab ketika mendapatkan amanah (kepercayaan) } \\
\text { dari orang lain }\end{array}$ \\
\hline 17. & Selalu menolong orang lain yang sedang kesusahan \\
\hline 18. & Suka bersedekah \\
\hline 19. & Tidak menghormati orang yang berbeda suku dan agama \\
\hline 20. & mbersihkan lingkun \\
\hline 21. & Tidak menjenguk teman dan saudara jika mereka sakit \\
\hline 22. & Tidak melanggar peraturan dimanapun saya berada \\
\hline 23. & Membuang sampah sembarangan \\
\hline 24. & Senang menjadi wargane \\
\hline & $\begin{array}{l}\text { Berupaya mengharumkan Negara Indonesia pada kancah } \\
\text { Internasional }\end{array}$ \\
\hline
\end{tabular}

Berikut skor rata-rata pada 25 item yang terdapat pada angket penelitian yang telah diberikan kepada siswa, untuk mengetahui hasil perbandingan akhlak siswa yang ber-asrama dengan akhlak siswa non-asrama yang disajikan dalam bentuk tabel dan diagram:

Tabel 2 Hasil Perbandingan Akhlak Siswa

\begin{tabular}{lrcrrrr}
\hline $\begin{array}{c}\text { Nomor } \\
\text { Item }\end{array}$ & $\begin{array}{c}\text { Skor Rata- } \\
\text { rata } \\
\text { Siswa } \\
\text { Asrama }\end{array}$ & $\%$ & $\begin{array}{c}\text { Skor Rata- } \\
\text { rata Siswa } \\
\text { non- } \\
\text { Asrama }\end{array}$ & $\%$ & $\begin{array}{c}\text { Skor } \\
\text { Maksimal }\end{array}$ & $\begin{array}{c}\text { Tingkat } \\
\text { Perbedaan }\end{array}$ \\
\hline Item 1 & 3,68 & $74 \%$ & 3,33 & $67 \%$ & 5 & $7 \%$ \\
Item 2 & 4,5 & $90 \%$ & 4,28 & $86 \%$ & 5 & $4 \%$ \\
Item 3 & 3,82 & $76 \%$ & 3,44 & $69 \%$ & 5 & $8 \%$ \\
Item 4 & 3,29 & $66 \%$ & 3,5 & $70 \%$ & 5 & $-4 \%$ \\
Item 5 & 3,71 & $74 \%$ & 3,72 & $74 \%$ & 5 & $0 \%$ \\
\hline
\end{tabular}


Perbandingan akhlak siswa berasrama dengan non asrama SMA Boarding School

\begin{tabular}{lrlrlrr}
\hline Item 6 & 3,96 & $79 \%$ & 3,28 & $66 \%$ & 5 & $14 \%$ \\
Item 7 & 3,29 & $66 \%$ & 3,56 & $71 \%$ & 5 & $-5 \%$ \\
Item 8 & 3,5 & $70 \%$ & 4,11 & $82 \%$ & 5 & $-12 \%$ \\
Item 9 & 3,21 & $64 \%$ & 3,11 & $62 \%$ & 5 & $2 \%$ \\
Item 10 & 3,5 & $70 \%$ & 2,89 & $58 \%$ & 5 & $12 \%$ \\
Item 11 & 3,61 & $72 \%$ & 3,44 & $69 \%$ & 5 & $3 \%$ \\
\hline Item 12 & 4,04 & $81 \%$ & 4,06 & $81 \%$ & 5 & $0 \%$ \\
Item 13 & 3,79 & $76 \%$ & 3,39 & $68 \%$ & 5 & $8 \%$ \\
Item 14 & 3,82 & $76 \%$ & 3,44 & $69 \%$ & 5 & $8 \%$ \\
Item 15 & 3,75 & $75 \%$ & 3,22 & $64 \%$ & 5 & $11 \%$ \\
Item 16 & 4,07 & $81 \%$ & 4 & $80 \%$ & 5 & $1 \%$ \\
Item 17 & 3,96 & $79 \%$ & 3,83 & $77 \%$ & 5 & $3 \%$ \\
Item 18 & 3,89 & $78 \%$ & 3,94 & $79 \%$ & 5 & $-1 \%$ \\
Item 19 & 4,54 & $91 \%$ & 4,67 & $93 \%$ & 5 & $-3 \%$ \\
Item 20 & 3,5 & $70 \%$ & 3,5 & $70 \%$ & 5 & $0 \%$ \\
Item 21 & 3,82 & $76 \%$ & 3,44 & $69 \%$ & 5 & $8 \%$ \\
Item 22 & 3,14 & $63 \%$ & 3,06 & $61 \%$ & 5 & $2 \%$ \\
Item 23 & 3,93 & $79 \%$ & 4 & $80 \%$ & 5 & $-1 \%$ \\
Item 24 & 4,46 & $89 \%$ & 3,83 & $77 \%$ & 5 & $13 \%$ \\
Item 25 & 4,36 & $87 \%$ & 3,94 & $79 \%$ & 5 & $8 \%$ \\
Total & 95,14 & & 91 & & 125 & \\
Persentase & $76 \%$ & & $73 \%$ & & $100 \%$ & $3 \%$ \\
\hline
\end{tabular}

$=$ Akhlak terhadap Allah

$=$ Akhlak terhadap diri sendiri

= Akhlak terhadap Lingkungan $\quad$ = Akhlak terhadap Manusia

Berikut hasil persentase bukan berdasarkan masing-masing item, akan tetapi disajikan berdasarkan gabungan item pada indikator tertentu:

Tabel 3 Hasil Persentase Berdasarkan Gabungan Item

\begin{tabular}{cccc}
\hline Indikator Akhlak & Siswa Asrama & Siswa non-Asrama & $\begin{array}{c}\text { Tingkat } \\
\text { Perbedaan }\end{array}$ \\
\hline $\begin{array}{c}\text { Terhadap Allah } \\
\text { Terhadap diri } \\
\text { sendiri }\end{array}$ & $79 \%$ & $73 \%$ & $6 \%$ \\
\hline $\begin{array}{c}\text { Terhadap Manusia } \\
\text { Terhadap }\end{array}$ & $75 \%$ & $73 \%$ & $2 \%$ \\
Lingkungan & $78 \%$ & $68 \%$ & $5 \%$ \\
\hline
\end{tabular}

Diagram 1 Perbandingan Akhlak 


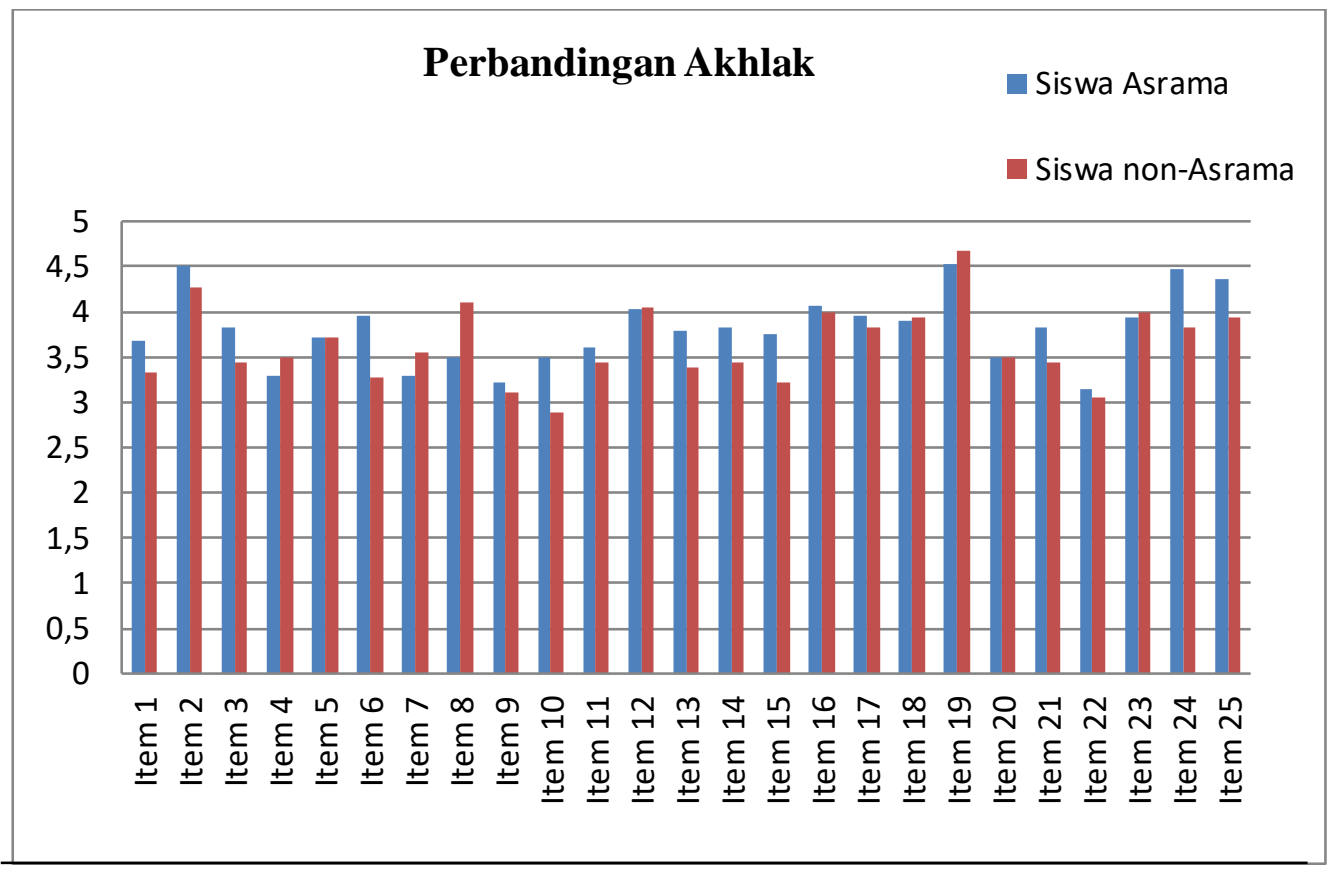

Setelah melihat tabel dan diagram, terdapat analisis peneliti secara deskriptif naratif diantaranya:

1. Pencapaian akhlak tertinggi siswa asrama dan non-asrama

Pencapaian akhlak tertinggi di SMA Pribadi Bilingual Boarding School Bandung adalah akhlak dalam menghormati perbedaan suku dan agama, dengan pencapaian skor rata-rata untuk siswa asrama 4,54 (91\%) dan siswa non-asrama 4,67 (93\%), dengan selisih hanya (3\%) untuk siswa non-asrama. Pencapaian besar ini dikarenakan SMA Pribadi Bilingual Boarding School Bandung mengayomi dan menerima siswa non-muslim dan mancanegara.

2. Pencapaian akhlak terendah siswa asrama dan non-asrama

Akhlak untuk senantiasa memaafkan orang lain meraih skor rata-rata terendah, yakni siswa non-asrama 2,89 (58\%) dan siswa asrama 3,5 (70\%). Hal ini menunjukan masa SMA memiliki regulasi emosi yang perlu pengawasan dan bimbingan yang sesuai dengan tumbuh kembang mereka dan siswa asrama mampu mencapai $12 \%$ lebih tinggi dibandingkan siswa non-asrama.

3. Perbedaan akhlak yang paling diunggulkan siswa asrama

Membaca al-Qur'an sebagai cara untuk membuktikan diri dalam ketaatan dan berakhlak kepada Allah Swt adalah perbandingan yang paling mencolok yakni dengan selisih $14 \%$ untuk siswa asrama. dengan skor rata-rata siswa asrama 3,96 (70\%) dan 3,28 (66\%) siswa non-asrama. Hasil ini disebabkan siswa asrama memiliki jadwal khusus menbaca al-Qur'an untuk setiap harinya dan dilaksanakan secara bersama-sama.

4. Perbedaan akhlak yang paling diunggulkan siswa non-asrama

Akhlak kepada orang lain yakni tidak berkata bohong adalah hal yang paling di unggulkan siswa non-asrama dengan selisih $12 \%$, siswa asrama memiliki skor rata-rata 3,5 (70\%) dan siswa non-asrama 4,11 (82\%). Hal ini disebabkan interaksi siswa asrama bersama rekan-rekan diasrama lebih banyak dibandingkan siswa non-asrama yang memiliki kesempatan interaksi yang lebih sedikit. Alangkah baiknya prinsip kejujuran lebih ditingkatkan, agar celah pada setiap keadaan dan kesempatan yang mengarah kepada kebohongan semakin tertutup rapat. Sehingga kebiasaan untuk senantiasa jujur dapat direalisasikan. 
5. Tidak ada perbedaan akhlak antara siswa asrama dan non-asrama

Akhlak untuk menjaga kebersihan lingkungan sekitar dan ke-istiqomah-an dalam beribadah baik suka ataupun duka, serta menjaga ketertiban umum adalah faktor yang tidak memiliki perbedaan sama sekali yakni selisih perbedaan nya $0 \%$. Maka siswa asrama dan non-asrama memiliki taraf yang sama pada tiga aspek tersebut dengan sebab pembinaan yang dilakukan di asrama pada aspek tersebut, juga dilakukan oleh para orang tua yang tidak menempatkan anaknya di asrama.

6. Perbedaan akhlak pada indikator umum

Indikator umum yang dimaksud, didapatkan dari item angket yang dikelompokan dalam empat aspek. Hasil perbandingan yang didapatkan untuk Akhlak terhadap Allah 6\%, siswa asrama 79\% dan siswa non-asrama $73 \%$. menunjukan bahwa spritual diasrama lebih bagus, sebab asrama menyediakan fasilitas Masjid yang nyaman serta mudah ditempuh dan (Shohbet) kajian keagamaan rutin. Pihak sekolahpun berusaha untuk meningkatkan spritual siswa asrama dan non-asrama untuk sholat beramaah zhuhur dan ashar. Meskipun demikian tidak menutup kemungkinan orang tua di rumah mampu mengajarkan prinsip islam lebih ketat dibandingkan diasrama untuk di terapkan dalam keseharian keluarga.

Akhlak terhadap diri sendiri hanya sangat sedikit perbedaan yang didapatkan, yakni $2 \%$ siswa lebih unggul, dengan persentase $75 \%$ siswa asrama dan $73 \%$ siswa nonasrama yakni dalam hal berupa berlomba-lomba dalam kebaikan dan bersungguhsungguh dalam belajar. Hasil yang didapat dikarenakan prinsip yang dimiliki diri sendiri adalah atas dasar kesadaran yang dimulai dari dalam hati untuk menentukan prinsip ataupun akhlak pribadi yang diinginkan sehingga faktor lingkungan tidak bisa memaksakan kehendak seseorang tapi keputusan yang tepat untuk meningkatkan akhlak terhadap diri sendiri pada jiwa seseorang adalah dengan menjadikan diri kita inspirasi dan teladan untuk mereka.

Akhlak terhadap sesama manusia memiliki perbedaan 5\% lebih unggul siswa asrama, dengan pencapaian siswa asrama $72 \%$ dan siswa non-asrama $68 \%$. sebab siswa asrama memiliki pengalaman yang lebih banyak dalam hidup berdampingan, yakni dalam hal tinggal dan tidur bersama, makan bersama, main bersama dan belajar bersama. Akhlak terhadap baik siswa asrama dan non-asrama sama-sama menerima pembelajaran di sekolah sehingga perbedaan kualitas akhlak siswa sangat sedikit.

Akhlak terhadap lingkungan yang dicapai siswa asrama adalah $78 \%$ sedangkan siswa non-asrama adalah $75 \%$ dengan selisih 3\%. Hasil ini didapatkan dari jiwa nasionalis para siswa yang telah tertanam dan sudah terbiasa untuk menjaga kenyamanan dan kebersihan walaupun ada sebagian siswa lupa untuk melakukannya. Hasil perbandingan yang sedikit ini menunjukan agar siswa lebih berusaha membiasakan dan menjaga kebersihan dimanapun berada.

7. Pencapaian akhlak secara keseluruhan

Angket yang telah disebarkan kesiswa serta hasil penghitungan yang telah dilakukan dari data-data yang sudah diterima, menunjukan perbandingan akhlak siswa asrama dengan non-asrama, sebagaimana dalam hipotesis penelitian ini menunjukan bahwa akhlak siswa asrama lebih baik dari akhlak siswa non-asrama, walaupun perbedaannya tidak signifikan, yakni siswa ber-asrama memiliki total skor sebesar 95,14 (76\%) sedangkan siswa non-asrama memiliki total skor sebesar 91,00 (73\%).

Sedangkan, skala perbadingan secara keseluruhan pada 25 item, antara akhlak siswa asrama dan non-asrama selisihnya sebesar 3\% di ungguli siswa asrama. Hal ini menunjukan peran asrama memiliki dampak positif yang sangat sedikit dan meningkatkan akhlak siswa bukanlah perkara mudah dan sekejap mata. Sebab 
peningkatan akhlak walupun dalam taraf yang sedikit itu sangat berharga untuk dijaga serta menambah harapan untuk meningkatkan potensi akhlak siswa lebih baik lagi serta masih banyak aspek yang bisa ditingkatkan oleh lembaga-lembaga tertentu melalui sistem asrama.

Hasil penelitian ini menunjukan bahwa apabila siswa berada di asrama dan waktu yang dimiliki secara maksimal digunakan untuk belajar dan beribadah serta terjaga dari lingkungan yang kurang baik maka akan meningkatkan akhlak siswa sedikit demi sedikit. Sebab peningkatan akhlak walupun dalam taraf yang sedikit itu sangat berharga untuk dijaga serta menambah harapan untuk meningkatkan potensi akhlak siswa lebih baik lagi.

\section{SIMPULAN}

Hasil penelitian perbandingan akhlak siswa asrama dengan non-asrama yang didapatkan dari seluruh item angket dengan skor maksimal 125 (100\%). Siswa asrama dan non-asrama meraih hasil perbandingan: 1) Kualitas akhlak siswa berasrama mendapatkan skor total 95,14 dengan rata-rata 3,8 dan persentase senilai $76 \%$ dengan penafsiran persentase hampir sebagian besar siswa sudah terbiasa untuk menjalani kehidupan dengan akhlak yang baik; 2) Kualitas akhlak siswa non-asrama mendapatkan skor total 91 dengan rata-rata 3,64, persentase senilai 73\% dengan penafsiran persentase hampir sebagian besar siswa sudah terbiasa untuk menjalani kehidupan dengan akhlak yang baik. 3) Perbandingan akhlak siswa asrama dengan non-asrama hanya 3\% masuk dalam kategori persentase sangat sedikit sekali. Hal ini menunjukan peran asrama memiliki dampak positif yang sangat sedikit dan meningkatkan akhlak siswa bukanlah perkara mudah dan sekejap mata. Sebab peningkatan akhlak walupun dalam taraf yang sedikit itu sangat berharga untuk dijaga serta menambah harapan untuk meningkatkan potensi akhlak siswa lebih baik lagi serta masih banyak aspek yang bisa ditingkatkan oleh lembaga-lembaga tertentu melalui sistem asrama.

\section{REFERENSI}

Afwan, B. (2017). Perbandingan Hasil Belajar Siswa di Asrama dan Siswa di Rumah Orang Tua. PESAGI (Jurnal Pendidikan dan Penelitian Sejarah) Vol 5, No 3 (2017). Di ambil dari http://jurnal.fkip.unila.ac.id/index.php/PES/article/download/12450/pdf_218

Dewantara, A. W. (2017). Filsafat Moral. Yogyakarta: PT Kanisius.

Firmansyah, M. J. (2018, September). KPAI: Tawuran Pelajar 2018 Lebih Tinggi Dibanding Tahun Lalu. Tempo. Diambil dari https://metro.tempo.co/read/1125876/kpai-tawuran-pelajar-2018-lebih-tinggidibanding-tahun-lalu $/$ full\&view $=$ ok

Ikhsanudin, A. (2018, Juli). Ada 504 Kasus Anak Jadi Pelaku Pidana, KPAI Soroti Pengawasan Ortu. Diambil 21 Maret 2019, dari https:/ / news.detik.com/berita/d4128703/ada-504-kasus-anak-jadi-pelaku-pidana-kpai-soroti-pengawasan-ortu

Lestari, D. (2019). PERBANDINGAN PRRESTASI BELAJAR SISWA YANG TINGGAL DI ASRAMA DAN YANG TINGGAL DI RUMAH PADA MATA PELAJARAN AGAMA KELAS XI IPA DI MADRASAH ALIYAH BAHRUL ULUM AIR EMAS. Jurnal AL-HIKMAH Vol 1, No 2 (2019). Diambil dari https://ejournal.uniks.ac.id/index.php/Alhikmah/article/download/313/180

Muftie, Z. (2017). PENGARUH KOMUNIKASI ORANG TUA DALAM RUMAH TANGGA TERHADAP AKHLAK ANAK SEHARI-HARI Zaenal. At-Thulab, II, 
Perbandingan akhlak siswa berasrama dengan non asrama SMA Boarding School

97-118.

Diambil

dari

http://journal.uinsgd.ac.id/index.php/atthulab/article/view/2725/1765

Nasution, R. (2003). Teknik Sampling. USU digital library.

Nurjaman, A. (2018). Studi Komparatif Sikap Syukur Siswa yang Mendapat Bimbingan Klasikal di SMA Babussalam Ciburial dan SMA Al-Falah Dago. Bandung: UIN Sunan Gunung Djati Bandung.

Sugiyono. (2013). Metode Penelitian Kuantitatif, dan R\&D. Bandung: Alfabeta.

Sunarti, K. (2015). Pola Asuh Orang Tua dan Kemandirian Anak. Makassar: Edukasi Mitra Grafika.

Syahriansyah. (2014). Ibadah dan Akhlak (I). Yogyakarta: IAIN ANTASARI PRESS.

Usroh, V. (2018). PERBANDINGAN PRESTASI BELAJAR GEOGRAFI SISWA BERASRAMA DAN NON ASRAMA DI KELAS XI IPS SMA ISLAM TERPADU AL-FITYAN ACEH BESAR. Jurnal Ilmiah Mahasiswa Pendidikan Geografi FKIP Unsyiah Volume 3, Nomor 1, Hal 94-104, Februari 2018. Diambil dari http://jim.unsyiah.ac.id/geografi/article/download/10783/4526. 